\title{
The Airman and the Weather
}

\section{Aeronautic Meteorology: A New Branch of Applied Science}

By Charles Fitzhugh Talman

A Eronautical meteorology is to the $A$ aeronaut what maritime meteorology and hydrography, together, are to the mariner. That it is destined to play an all-important part in the navigation of the air is so obvious as to require no demonstration. Taking this for granted, there are, however, certain questions to be answered in order to fix the status of this branch of knowledge in the aeronautical curriculum. How much, actually, do we know about the laws of the atmosphere bearing on aeronautics? Has the science reached a practical stage, or is it still so tentative and uncertain that, for the present, the individual aeronaut should look upon his personal experience as a safer guide than the generalized knowledge now available? Is the meteorologist still, as formerly, learning more about the free atmosphere from the aeronaut than the latter is learning from the meteorologist?

If for any reason the world became interested in blowing soap bubbles we should not have long to wait for an exhaustive "Lehrbuch der Seifenblasenkunde" from Germany. It was in the normal order of events that a German gave us the first text book of aeronautical meteorology ${ }^{1}$, and that we are promised from the same pen a companion work on aeronautical climatology; but it is safe to say that few meteorologists were prepared to find in Dr. Linke's pioneer work a complete new branch of applied science, embodying a wealth of information not only useful, but indispensable, to every person who risks life and limb in navigating the air. This book fully answers the questions we raised a moment ago. Aeronautical meteorology has arrived.

The present writer has reviewed Linke's book in the Scientific American (June 24th, 1911, p. 630, and April 20th, 1912, p. 368), and it is not necessary to repeat here what has already been said about its many merits. The young German author, though himself a practical aeronaut as well as a meteorologist, is of course primarily a mere spokesman for the scientific aeronauts of his country, and his work refiects credit upon many besides himself. Our purpose now is simply to cite a few facts from the work in question, and from other recent literature, serving to show to what extent meteorology is already prepared to take up the new. tasks imposed upon it by the sudden efflorescence of the art of aeronautics.

It was a providential circumstance that meteorologists had made a substantial beginning in the systematic study of the upper air a few years before the invention of the first practical aeroplanes and dirigible balloons. The new science of aerology-i. e., the survey of the atmosphere throughout its vertical extent, by all possible methods-dating, as a coherent body of knowledge, from about the beginning of the present century, pushes its investigations some three hundred miles above the earth. The balloonist, in extreme cases, rises $61 / 2$ miles; the aviator, $21 / 2$ miles Thus it happens that much of the matter of aerology has no direct bearing on aeronautics. Even the remarkable isothermal layer, or stratosphere, the discovery of which, in the year 1902, marked an epoch in the history of science, lies a such an altitude that it is doubtful whether any human being will ever trave up to its lower boundary; though. it is now almost daily entered by unmanned balloons carrying self-registering instruments. As to the lofty regions, beyond the reach of the sounding-balloon, in which the atmosphere is no longer "air," but hydrogen, or helium, or "geocoron${ }^{1} \mathrm{~F}$. Linke, Aeronautische Neteorologie, vols, Frankfurt a. M., 1911.

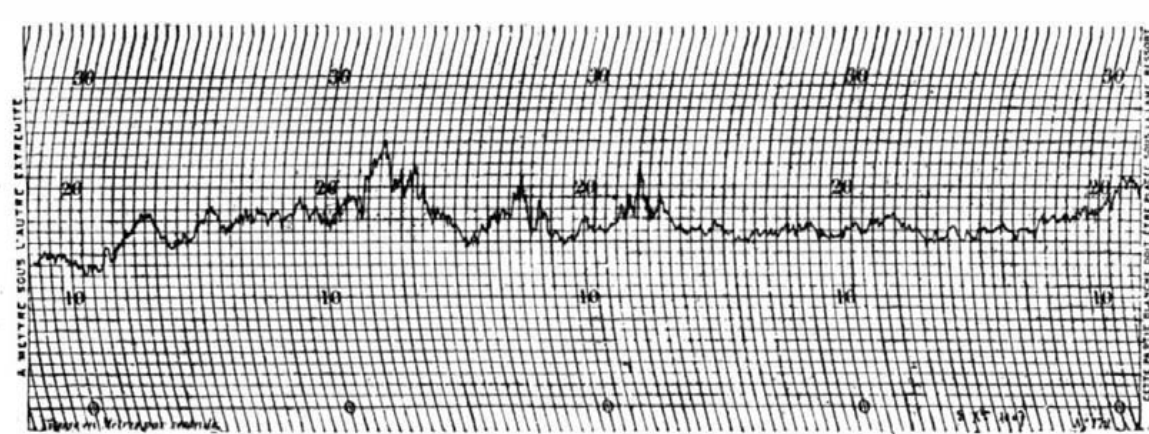

Fig. 1.-Gustiness of the wind. Shown by the record of a Richard anemocinemograph. The speed of the wind at each moment is here registered in meters per second.

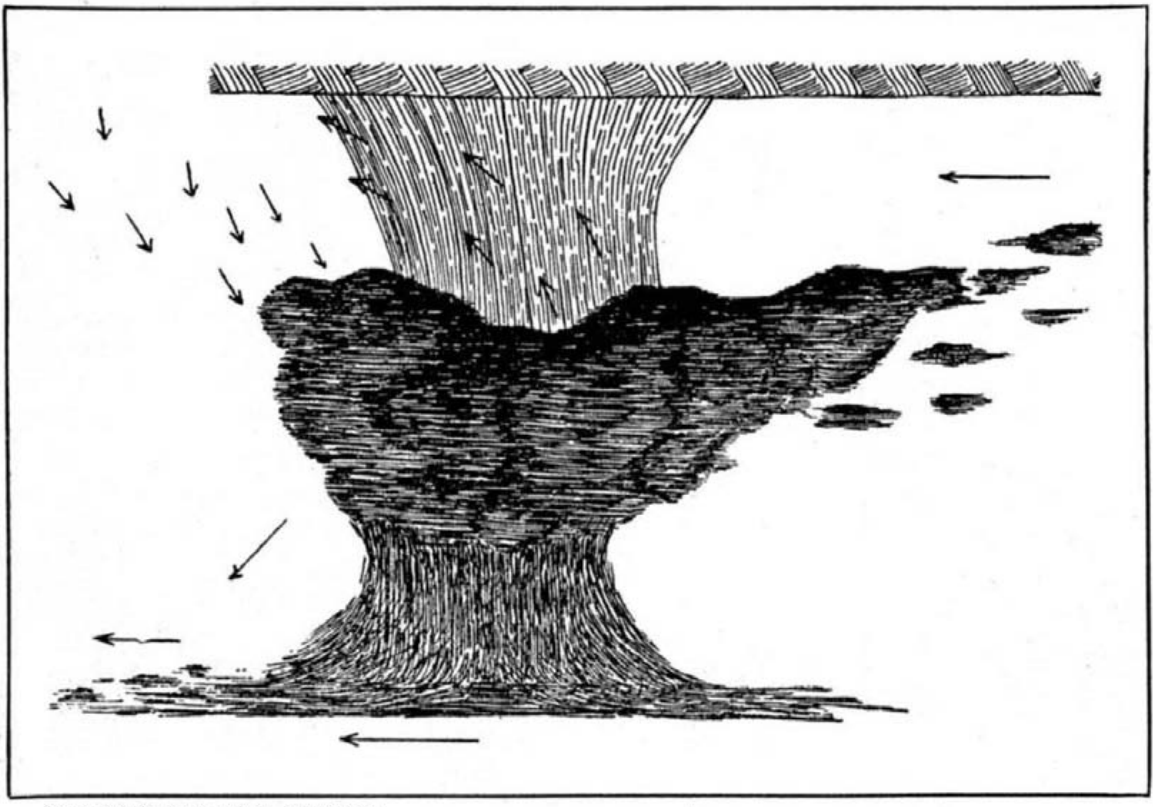

Hig. 2.-"It is notorious that the greatest enemy of all kinds of air-navigation is the thunderstorm; . . . not only because of its electrical dangers, but because of the strong vertical air movements by which it is attended."-Linke.

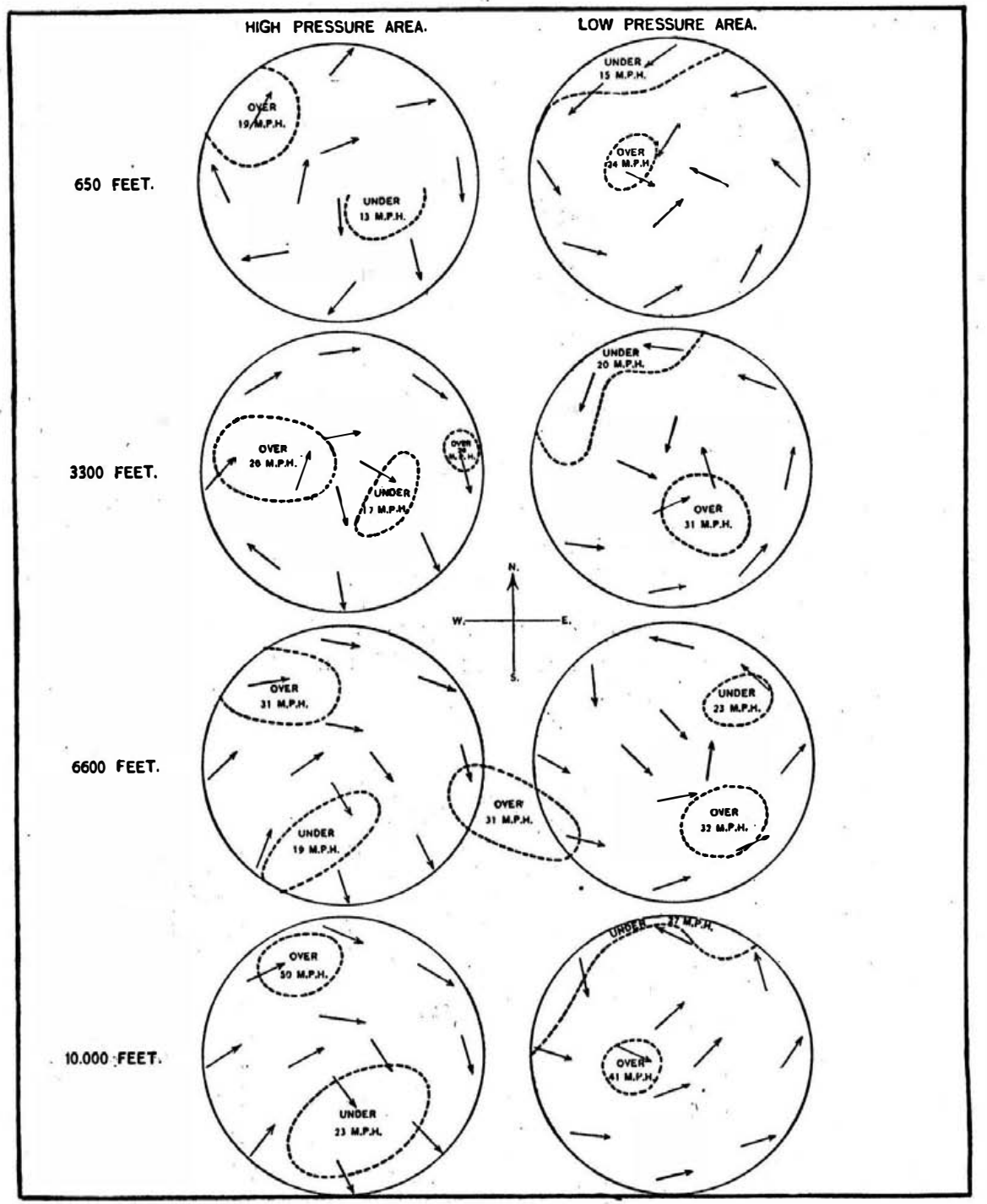

From Rotch and Palimer's Chares of the Atnoopherr (Now York, 1911: Jobn Wiley \& Bonal.

Fig. 3.-Variations of the force and the direction of winds at different altitudes in high and low-pressure areas. ium," or what-not, these are of no more practical concern to the aerial navigator than to the prosaic wayfarer on terra firma.

However, in order to reach the stratosphere every sounding-balloon must pass through the troposphere, and all ascents of meteorological kites are confined within this lower stratum. Thus the great bulk of the data acquired by the aerologist pertains to regions accessible to the aeronaut.

Before all things else the aeronaut is interested in the wind. The combined labors of the aerologist and the aeronautical engineer have completely upset oldfashioned ideas concerning this element. No longer do we think of a wind as a steady horizontal stream of air, in which every particle is moving at the same speed as every other particle. Such a wind would be a boon to the aeronaut if it existed, but it does not-as was first conclusively proved by Langley, and as is shown in the record of every aerological observation. In the first place, a wind is rarely horizontal, but has, instead, a more or less pronounced vertical component, of which the ordinary wind-vane and anemometer give not the slightest token. In the second place, no wind is absolutely steady or homogeneous; and most winds are quite the reverse. When two anemometers are placed side by side, a few feet apart, one of them may, for a brief period, indicate a velocity twice as great as the other. Moreover, a single anemometer, if sufficiently delicate, will show incessant fiuctuations in the strength of the wind. This "gustiness" is not well brought out in the records of the ordinary registering anemometer, but it is strikingly shown in those of the Dines pressure-tube anemometer, or the Richard anemocinemograph (Fig. 1), or the apparatus attached to the winch of a meteorological kite for recording the tension on the kite-wire.

That the wind commonly has a vertical component, that gustiness is the rule rather than the exception, and that great variations in velocity occur from one place to another, are facts that the aeronaut would soon find out for himself. It is the business of the meteorologist to tell him under what conditions he may expect these features to be most pronounced or most persistent, and what limiting magnitudes they may assume.

For example, the meteorologist teaches the aeronaut to distinguish the typical forms of clouds, for the very practical purpose of enabling him to recognize those forms which are characteristic of vertical air movements, and those which denote mainly horizontal movements. A cumulus cloud is proof positive of the existence of a strong ascending current beneath it; while in the intervals between neighboring cumuli the air is likely to be sinking. Prof. Humphreys has happily described these vertical movements as "aerial fountains" and "aerial cataracts," and has shown that they are among the numerous causes of the so-called "hole in the air."

What maximum speed may be attained by vertical air currents? This is a question that the aeronaut would hardly care to have answered by a personal encounter with the extreme case of the phenomenon. The meteorologist, with the statistics of almost innumerable observations at his command, is able to tell him that ascending currents sometimes move at the rate of 25 or 30 feet a second, and that these rapid movements in the vertical occur especially in connection with thundersqualls. Furthermore, the meteorologist (Ooncluded on page 101.) 


\section{Good Bearing Metal}

Good Bearing Metal means long lived bearings. And long lived bearings means a long lived machine requiring little or no attention and

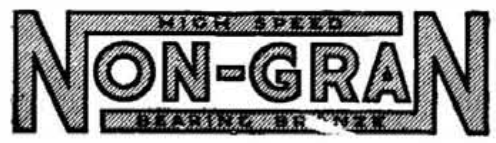

NON-GRAN resists wear for f:om three to five times
other bearing bronze.

That is why the E. I. Du Pont de Ne mours Powder Company invariably use NON-GRAN when they have to replace the original bearings in their manufacturing equipment. NONGRAN costs them more than any other bronze, but once it is in place it from three to five times longer than from three to five times longer than could any other metal. Scores keeping their machines in more conminimizin maintenance cost in just this same way.

A bearing wears out because friction constituting the bearing metal. That
is why the inside diameter of a bearing keeps getting larger and larger as wear goes on. The particles simply being pulled right out from the bod

In direct contrast with other bearing bronzes, NON-GRAN is non-granular in structure. The whole mass is
of a tough cohesive structure. Each of a tough cohesive structure. Each of the billions of constituent particles
is securely knit to all adjacent particles. This enables the particles on
the bearing surface to resist the frictional pull to which they are subjected.

Do you want to save money on the maintenance of

Drop us a line to-day and we will give you full dabe
regarding this wonderful metal which i in annually
saving hundreds of thousands of dollars to those

AMERICAN BRONZE CO. 1733-1757 CARTON BLVD. BERWYN, PENNSYLVANLA

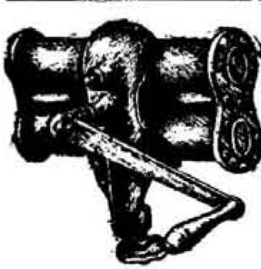

A G E N T S Send for our proposiFour Cylinder Automobile Hand Air Pump. HAWTHORNE MFG. CO.,Inc.
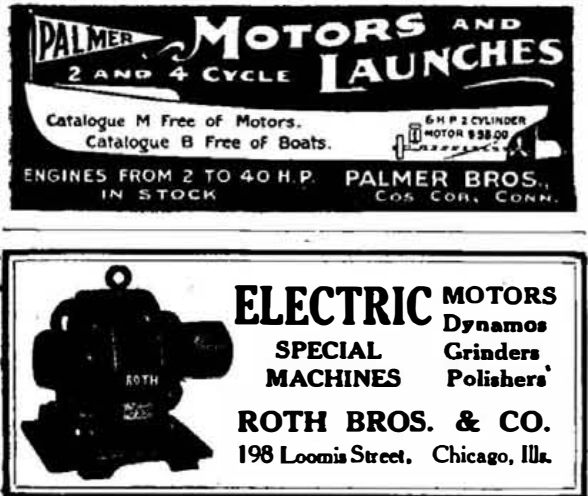

CRUDE ASBESTOS DIRECT FROM MINES

\begin{tabular}{c|c} 
PREPARED & R. H. MARTIN \\
Asbestos Fibre & OFFEE, ST.PAUL BUILDING \\
\cline { 1 - 2 }
\end{tabular}

$\begin{array}{ll}\text { for Manufacterers ase } & \text { OFFICE, ST.PAUL BUILDING } \\ \end{array}$

C. MACHINES Corliss EngInes. Brewers The VILTER MFG. CO.

899 Clinton Street,

Milwaukee, Wis.

Magical Apparatus

Grand Book Oatalog. Over 700 engrav-

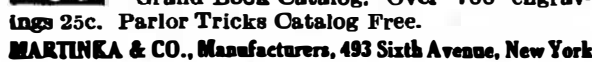

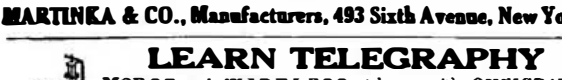

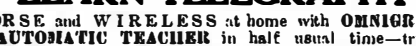

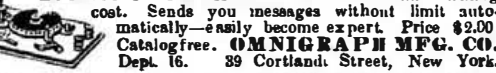

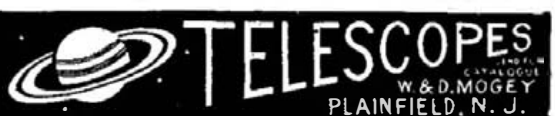

nuclear division figures, with various kinds of outgrowths, had been described by Leduc in earlier writings, together with the osmotic growths of various kinds, suggesting molds, sea-weeds, toadstools, etc. Both series of phenomena were re ferred to and illustrated in the ScIEnTIFIC AMERICAN, September 9th and 23rd, 1911. Fig. 4 is a reproduction of one of Leduc' "artificial" nerve cells, shown alongside of a ganglionic cell (Fig. 5) prepared by Demoor according to Golgi's method. Leduc's "cell" was produced by placing a "seed" consisting of two parts of copper sulphate and one part of cane sugar in a solution of ferrocyanide of potassium. precipitate of copper ferrocyanide is formed on the surface; this is impervious to sugar, but water is readily absorbed through it, leading to "growth" in all directions, the final form depending upon the precise distribution of the particles of sugar and of copper sulphate in the grain, upon variations in the density of the medium, etc.

Much of the argument in the book is devoted to showing that the lines of dynamic discharge are essentially the same in an organism and in organic media. To this end illustrations are derived from comparison of electric discharges and crystallization figures with ferns and other plant structures. Fig. 8 is the electric discharge resembling a leaf; Fig. 10, an electrolytic pattern suggesting a fern monium chloride in gelatin suggesting plant forms; Fig. 9, four successive stages in "karyokinetic" figures produced by diffusion; Fig. 12, a modification of diffusion currents by contact of a glass rod, illustrating irritability; and Fig. 13 shows "negative heliotropism" of diffusion currents of India ink in salt solution.

With wonderful patience and ingenuit Prof Leduc has taken up in turn the commonly recognized characteristics of living cells-their structure, their absorption of nutrients, their nuclear division, their irritability, the circulation, the relation of temperature to function, their transformation of energy - and has reproaration which is admittedly "non-living." But has he thereby made an approach to the artificial synthesis of life? All that we can learn from these experiments
that the laws of motion and of matter as evident in the world of living things as in the world of non-living; that motion here is along the line of least resistance
as it is there; that the mechanics and the electrics and the chemics of living cells are the same as those of non-living systems.

The chapter on the origin of life and spontaneous generation is a sane statement of the problem, and in it Dr. Leduc points out the logical necessity of assuming that life not only did originate "spontaneously"-in a scientific sense-but may do so again under suitable conditions. He also points out the evasion of the issue arolved in such theories as that of Arrhenius in regard
origin of life.

Whether the methods of Leduc ever reach the bottom of the problem or not, these experiments have their value in clearing the field of much conjectural rubthesis-that has not yet reached the ex perimental stage.

The Airman and the Weather (Continued from page 94.)

now able to draw a vertical plan of the thundersquall (Fig. 2), tracing its as a guide to the maneuvers the airman should adopt if overtaken by a storm of this character. This is strikingly analogous to the task of the nineteenth century meteorologist in tracing the ground plan of the cyclone, and teaching the mariner how to avoid the "dangerous semicircle."

However, the aeronaut needs horizontal sell as vertical plans of the wind systems he is likely to encounter-cyclones nd anticyclones, land and sea breezes,

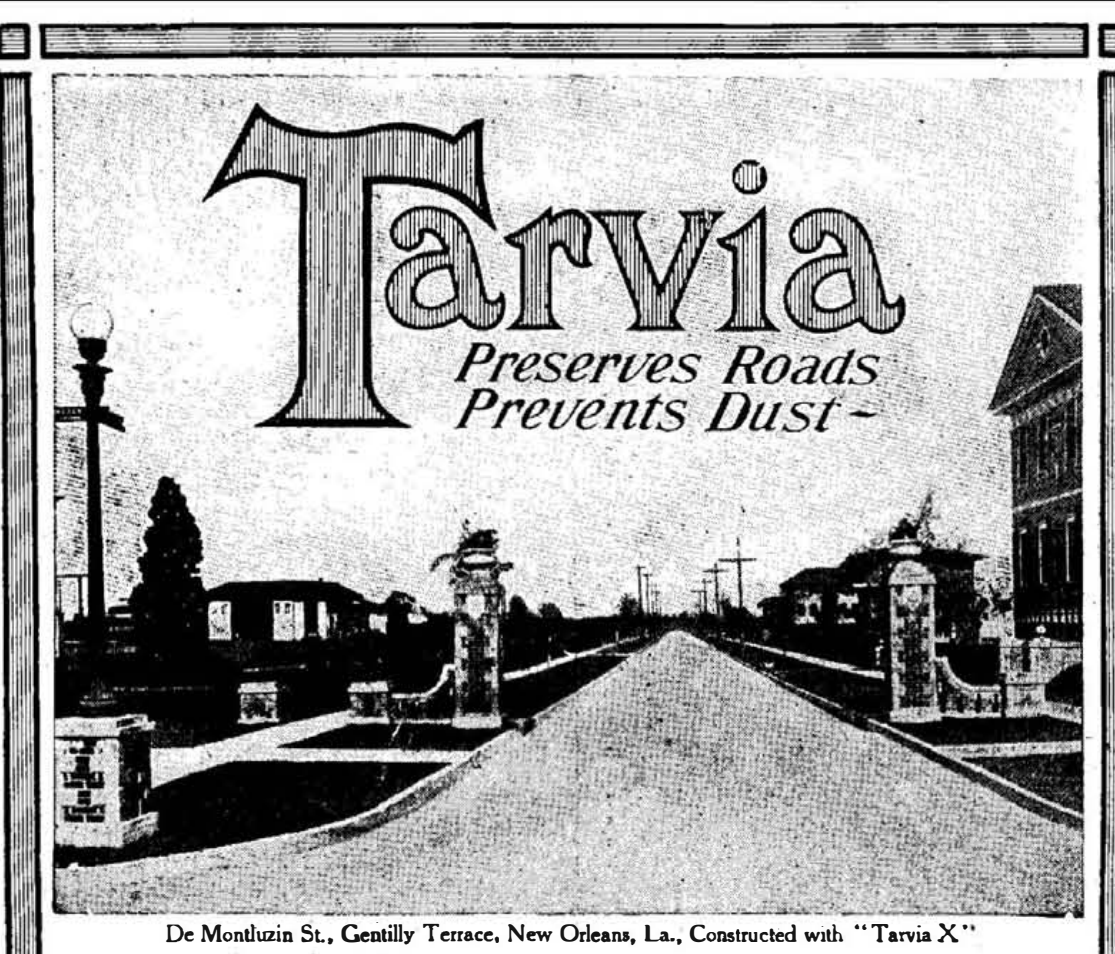

Fifty Million Yards Treated

THE rear wheels of an automo- used successfully on over 50,000 . bile revolve more times to a mile than the front ones do.

There is a certain amount of slip when the car is driven at high speed and this slip exerts upon the road surfaces a powerful and destructive abrasive effect exactly like that of an emery wheel.

Ordinary macadam never was expected to withstand such strains and soon goes to pieces unless it is given constant and costly care.

A macadam road, to meet the demands of modern traffic, requires the use of an additional binder to reinforce the surface. Tarvia is OOO yards of roadways and pavements in this country. as a surface application.

There is such a vast economy in maintenance expense that it more than balances the cost of the Tarvia treatment.

Tarvia is made in three grades"Tarvia X," very heavy and dense for road construction where the voids are large; "Tarvia A," a lighter grade for the smaller voids which occur in surface operations; "Tarvia $B, "$ applied cold for dust sup.
pression and surface maintenance. Booklets on request.

BARRETT MANUFACTURING COMPANY

New York Chicago Philadelphia Boston St. Louis Kansas City Clevclind
Cincinnati Minneapolis Pittsurgh Seattle Corey, Ala.

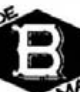

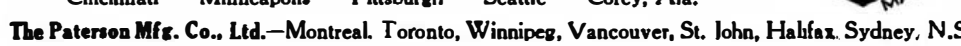

T The CONSTRUCTION of an INDEPENDENT INTERRUPTER

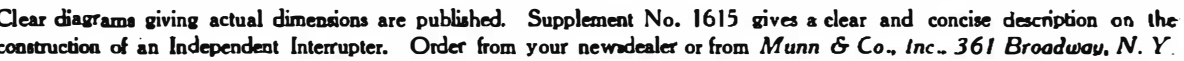

Handsome Structures Everywhere Built with $\underline{\mathrm{Hy}}$ - Rib

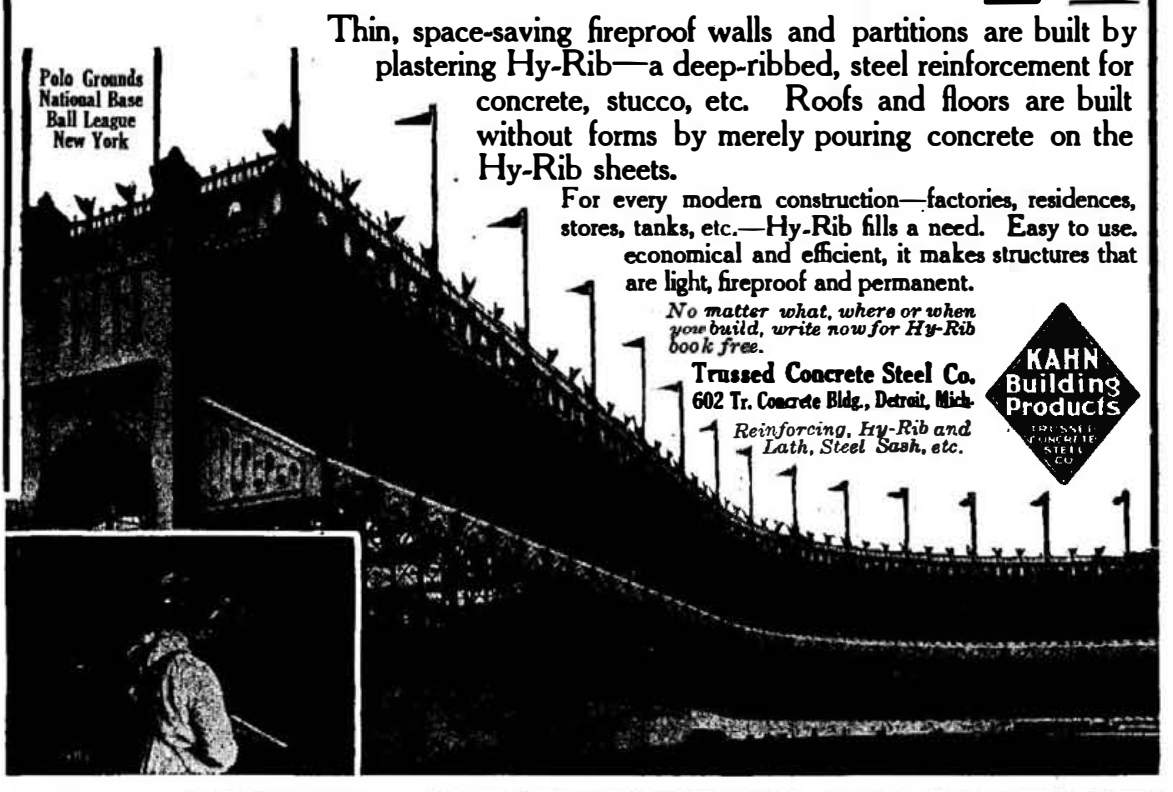

THIS IS THE NEW FOX No. 24

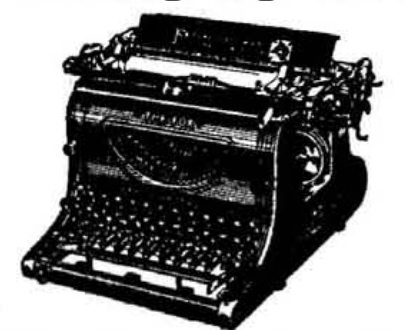

Better Than the Best of All Others" SAMPLES AT WHOLESALE

Agents wanted-big commissions-monthly payments - trial shipments-new stock-visible models - lowwholesale prices. Newadvertising now ready Write today for Agency offer. Mention Scientific American. $\begin{array}{ll}\text { Fox Typewriter Company } & \begin{array}{l}\text { Name... } \\ \text { Address. }\end{array} \\ \text { GRAND RAPIDS, : : MICHIGAN } & \text { Business. }\end{array}$ 


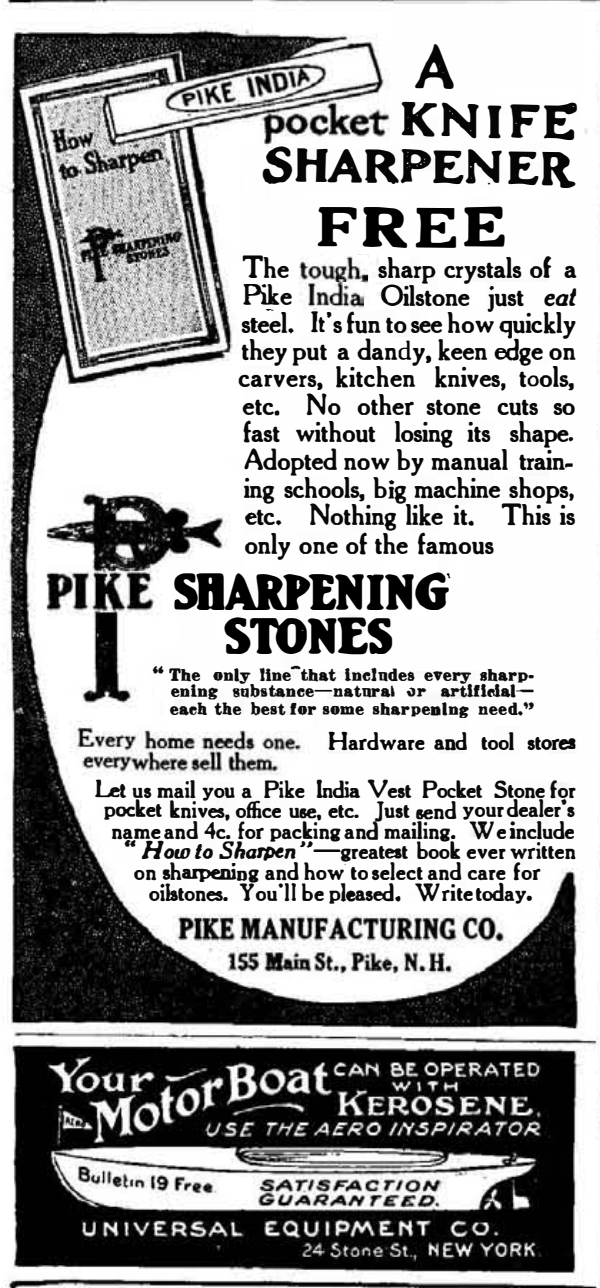

Scientific and Technical BOOKS

$W_{\text {scientific and technical books, which will }}^{E}$ be ready for distribution about April 15,th. This catalog will contain the tites and descrip-
tions of 3500 of the latest and best books tions of 3500 of the latest and best books
covering the various branches of the useful covering the vario
arts and industries.

Our "Book Departmen" can supply these published and forward them by $m$ mol press prepaid, to any address in the world on receipt of the regular advertised price. Send us your name and address, and a copy
of this catalog will be mailed to you, free of MUNN \& CO., Inc.

361 Broadway New York, N. Y.
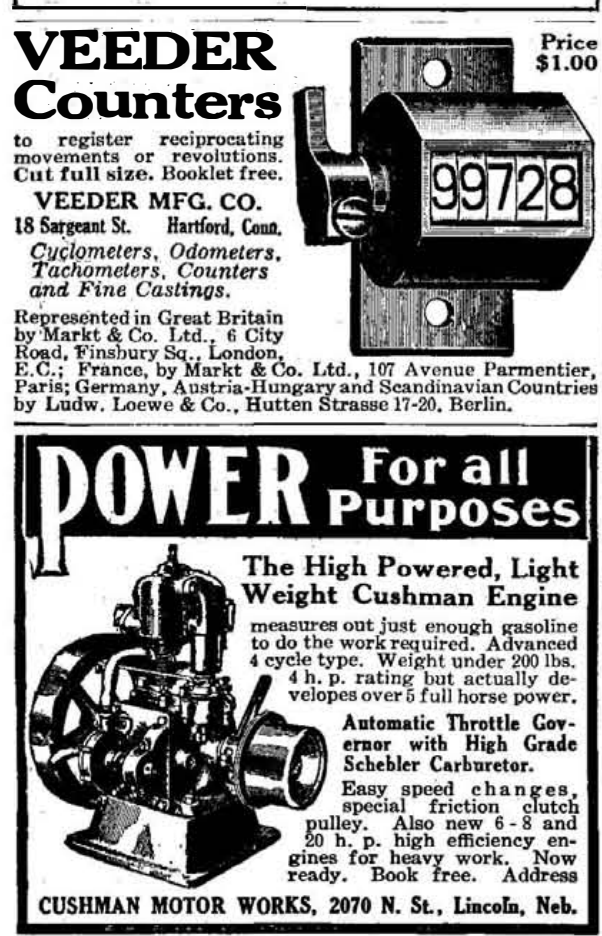

BRISTOL'S RECORDING

Pressure Gauges, Vacuum Gauges, Draft Gauges, Differential Pressure Gauges, Thermometers, Pyrometers, Voltmeters, Ammeters, Wattmeters, Motion Meters, Tachometers and and day records.

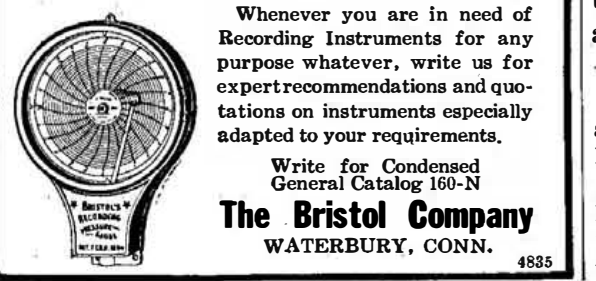

other members of the atmospheric circula- tions these gradients are likely to be in tion. He needs to know, for example, the terrupted or reversed. The typical ver
relation of the winds to the isobars at vari- tical and horizontal distribution of tem relation of the winds to the isobars at vari- tical and horizontal distribution of temous levels in a typical cyclonic disturb- perature in cyclones and anticyclonesance. It is a distinct advantage to him subject concerning which very erroneou to learn that, while at the earth's surface opinions formerly prevailed-

the center of a depression, at the milethe other meteorogical \begin{tabular}{l|l|l} 
level overhead they are no longer inclined & ments. Each of them, thanks to the ad \\
inward, but blow in such a direction that & vent of aerology, has now been studied for \\
val
\end{tabular} the isobars on the surface weather map several years from the three-dimensional correspond approximately with the motion point of view,
of a free balloon at such a level. Thus of aeronatics.

eronautical meteorology, which is science of three dimensions, is vastly more complicated than marine meteo
ology, which is a science of only two. Let us repeat, however, that in spite of the magnitude of the tasks imposed upon it, aeronautical meteorology has utility. A single illustration will make this clear. Suppose plans were on foot to this clear. Suppose plans were on foot to the Atlantic, where would be the most favorable route?. Meteorology is ready to answer this question. For the westward journey there is one region, and one only, out the sear, viz., the trade-wind belt. For the eastward journey a sea-level wind hart might suggest the advantage of more northerly route, in the zone of "prevailing westerlies." Aerology, however, an better this suggestion. The winds of terms of averages and resultants, are actually subject to the vicissitudes attending the frequent passage of cyclonic disturbances. There is oply one region in which there is a tolerably steady drift from west to east, and this is the-zone of the antitrades, ${ }^{2}$ lying vertically over the trade winds. Hence the flrst transistlantic airhips will probably sail from southern Europe to the West Indies at a low level, and return in the same latitudes at a level few thousand feet higher. The tropical hurricanes that occasionally invade this region during the late summer and early autumn will be announced by wireless telegraphy from the meteorological bureaus, and the aerial liners will give them a wide berth-or possibly rise to the a the storm itself and take advantage of the outflowing winds at that
level to get away from the storm center. A to get away from the storm center. Aerologists have now been at work for trade-wind belt. The trades are found to be quite shallow, and their depth varies considerably with latitude.

We have not space here for even the most summary digest of the science of aeronautical meteorology, but must limit ourselves to an enumeration of its prin-
cipal subdivisions. We have already devoted considerable space to the wind, as the subject of capital importance. Under his head let us add that valuable statistics have been compiled as to the varia-
tion of the force and the direction of the tion of the force and the direction of the
wind with altitude (see, for example, wind with altitude (see, for example, of various places on the earth's surface has been determined, in order to point out the most favorable locations for aerial harbors and aerodromes; that the
relation of the winds at moderate altitudes to the topography of the land has been worked out in great detail; and that ingenious forms of apparatus (e. g., the vertical anemometer and the pilot-bal-
loon) have been devised, to supplement the ordinary anemometer and wind-tane for aeronautical purposes. The elaborate investigations on wind pressure and the like carried out in aerodynamic laboratories, belong to engineering rather than Temperature is a very important factor in ballooning; less Important in aviation. Here, again, aerology has gathered a great fund of information. We know not only the normal temperature gradients in the atmosphere, but also under what cond

2 The term "antitrade" is sometimes used in a broad sense to include not only the high-
level wind above the trades, but also the sup posed extension of this wind at sea-level in higher latitudes, i. e., the "westerlies" of the temperate zone. It is here applied to
upper current of the tropical belt only.

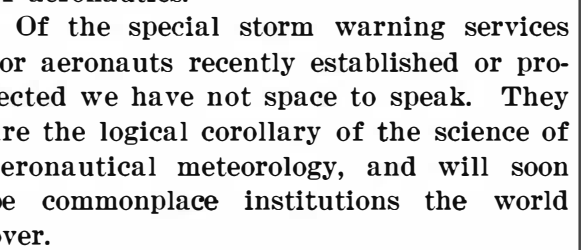

Device for Detecting Flight of Mosquitoes

By L. E. Haskell?

$A^{N}$ instrument for detecting the direc Deen put in operation with a great dea success on the Isthmian Canal Zone ritment of Sanitation on the Canal Zone rfected his device for the purpose dding the more

The device consists of a metal fram holding four plates of glass each 12 by 12 ches in size, placed upon a tripod. Tia ngles to one another, so that when the in trument is set up, they point north, east

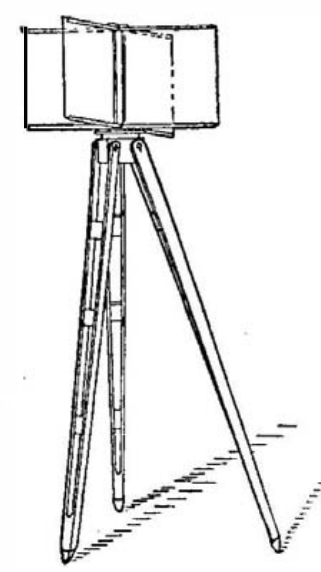

Device for detecting the flight of mosquitoes.

outh and west. To catch the mosquitoes, pound of rosin to one liter of castor oil, epared, and when applied

Many interesting and important facts been learned. It was found that the adult mosquito flew on the quarter of an eighflight occurred between $6: 10$ and $7: 10$ clock; that there was a complete lull in there was a return flight between $5: 50$ and $6: 40$ o'clock in the morning, also on the ind's quarter.

The instrument has proved to be use ting the area facing the plates that $d 0$ wot show a catch. It has established means of flnally exterminating mosqui-
toes on the Canal Zone. The device point out the direction of the breeding places: thorough search; the discovery sirampy ground or pools of stagnant waplace is clean.

A Combined Life-boat and Marine Safe. The patent No. 1,064,472, to August

aas of Grapeville, Penn., shows a shi wall of the ship and having downwardly and outwardly inclined slideways with an emergency boat having its greatest depth at its stern and decreasing in depth toward
its bow and supplied with runners so that it can be supported on the slideways, with securing means for
boat in the berth. ht of adult mosquitoes has egarding the habits of the mosquito have
Valuable. Books

\section{The Modern Gasoline} Automobile

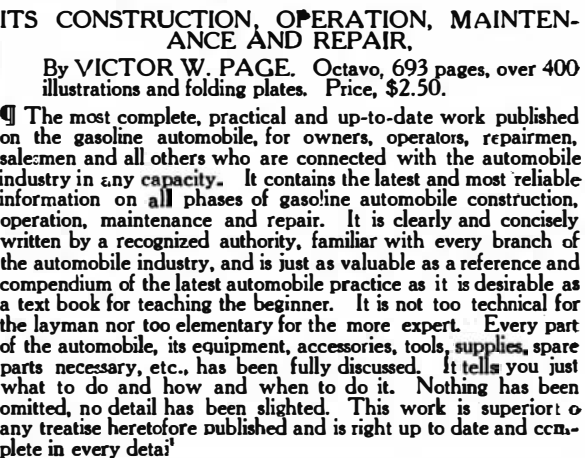

Scientific American

Reference Book

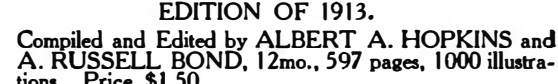

a A handy, compact, reliable and up-to-date volume for every-
day reference containing a remarkable aggregate of factsos statis-

ific and mechanical lines of interest to everyone. This volume
is a revelation in the nature of facts and figures relating to popu-
lation, manufactures, commerce, railroads, shipping, mining

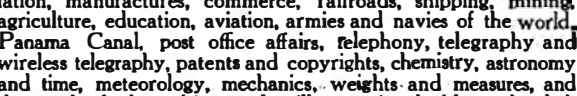

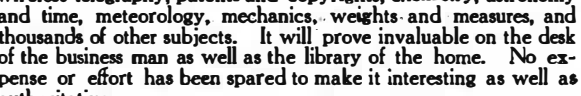

Wireless Telegraphy and

Telephony Simply

Explained

By ALFRED P. MORGAN. 12 mo, 154 deges, 156

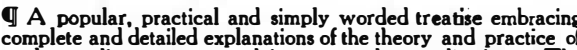

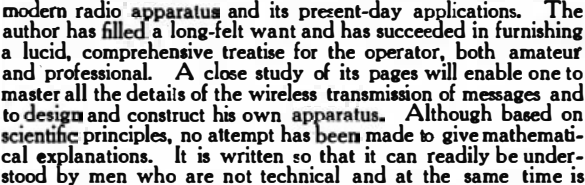

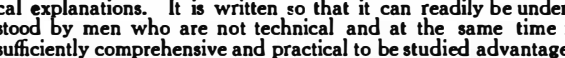

The Scientific American

Handbook of Travel

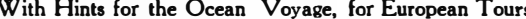

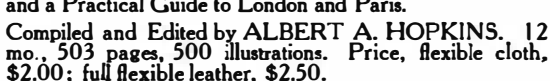

IT This is an indispengable companion for the European tourist,
and contains more miscellaneous information on travel and sub-

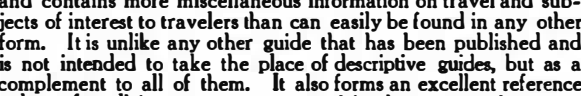

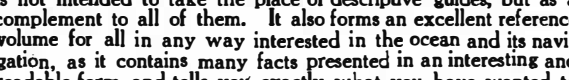

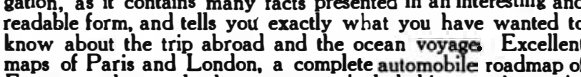

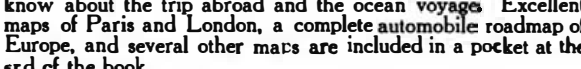

The Scientific American Cyclopedia of Formulas

Edied by ALBERT A. HOPKINS. Octavo, 1077
pages.
$\$ 650.000$ Reccipts. Cloth, $\$ 5.00 ;$ half morocco,

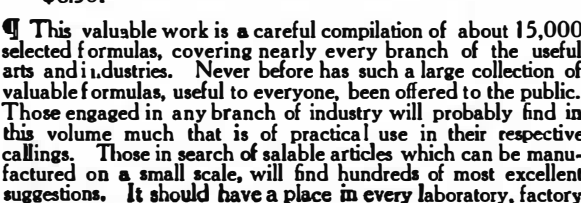

Concrete Pottery and Garden Furniture

By RALPH C. DAVISON. 16mo., 196 pages, 140

I This book describes in detail in a most practical manner the
various methods of casting concrete for
vanamental and suseful

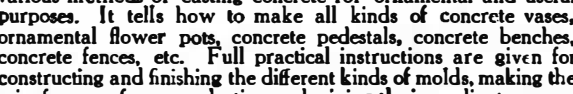

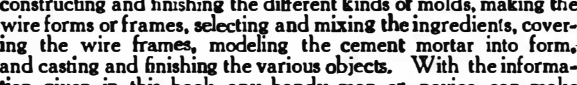

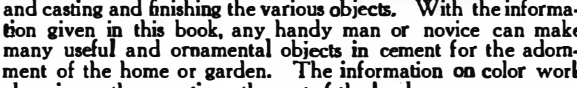
ment of the home or garden. The inform
alone is worth many times the cost of the bood

Any of these books will be sent postMUNN\& CO., Inc., Publishers 361 Broadway, New York City 